\title{
Reconsidering dragon carpet origins
}

\author{
Gerald Pollio
}

Fordham University, London Study Centre, 2 Eyre St Hill, London EC1R 5ET, United Kingdom

gpollio@aol.com

\begin{abstract}
Armenians have increasingly been eliminated from the weaving history of the Caucasus. Given that Armenians have lived there for millennia and are its only inhabitants attested in both ancient and medieval sources as having been weavers and dyers, it is surely curious they would have abandoned a craft for which they were renowned. Many regional rugs were originally attributed to Armenian weavers, but from the second quarter of the 20th century onwards were reclassified as being either of Turkish (Azeri) or Persian origin. This article reconsiders the available evidence and the way it has been interpreted to arrive at a balanced assessment of Armenians' contribution to the production of Dragon carpets, the region's earliest surviving design. Its findings challenge many of the assumptions upon which these conclusions were based, and thus revives the possibility the attributions of earlier authors were more accurate than those of their successors.
\end{abstract}

\section{Reconsiderando as origens do tapete de dragão}

\section{Resumo}

O povo arménio tem vindo cada vez mais a ser eliminado da história da tecelagem caucasiana. Dado que os arménios viveram na região durante milénios e são os únicos habitantes reconhecidos como tecelões e tintureiros em fontes da Antiguidade e da Idade Média, é certamente curioso que tenham abandonado uma actividade pela qual foram tão famosos. Inicialmente, muitos tapetes da região foram atribuídos a tecelões arménios, mas, desde o segundo quartel do século XX, foram reclassificados como sendo de origem turca (azeri) ou persa. Este artigo reconsidera a evidência disponível, e o modo como esta tem sido interpretada, para chegar a uma avaliação ponderada sobre a contribuição do povo arménio para a produção de tapetes de dragão, o mais antigo padrão conhecido da região. Os resultados desafiam muitas das suposições sobre as quais têm sido baseadas aquelas conclusões e, deste modo, recupera a possibilidade de as atribuições feitas pelos primeiros autores serem mais rigorosas do que as feitas pelos seus sucessores.

\section{Keywords}

Design origins

Dragon carpets

Caucasus

Armenians

Historiography

\section{Palavras-chave}

Origens de padrões

Tapetes de dragão

Cáucaso

Arménia

Historiografia 
Armenians are an ancient people that inhabited an area of the Near East bounded by the Mediterranean and Black Seas and the southern Caucasus. It thus describes the region which from $c$. $600 \mathrm{BCE}$ to the 12th century CE was politically and ethnically Armenian; after that time, although not politically independent, the area was inhabited principally by Armenians until the early part of the 20th century. Whether Armenians constituted part of the region's aboriginal population, or were migrants has yet to be established. It hardly matters: literary evidence confirms they lived in this region for more than two millennia, and if the genetic evidence is credible, even longer than that.

Like the Kurds, who also lived in the Caucasus for centuries, from the standpoint of rug scholarship both have effectively been written out of the region's history; if they did weave rugs, they were invariably kilims or other flat woven textiles intended mainly for personal use, barter or local trade. Commercial production was restricted mainly or entirely to Turks, a rather curious inversion given that nomads would seem to favour smaller and lighter flat weaves over larger and heavier piled carpets. The Turkmen, of course, were transhumants, while the Byzantine (Greek) and Armenian inhabitants of the Caucasus had long been settled and lived in villages and cities.

There are two dimensions to the elimination of Armenians from the region's carpet history. The first has to do with intellectual battles fought in the first half of the 20th century between scholars who, on the one hand, favoured a Turkish origin for the piled carpet and those, on the other, who insisted upon the priority of the Persians. The key implication, of course, is if the Armenians did weave carpets, they could only have learnt the craft from the Turkish invaders or adapted the designs of the more technically and aesthetically advanced Persians. In more recent years, the debate has become increasingly politicised, with attempts made to exclude Armenians from the cultural life of the Caucasus.

With respect to carpets, advocates of this position insist either Armenians never wove carpets [1] or, with the possible exception of Karabagh, that production in Armenia itself is a relatively recent phenomenon, possibly dating back no further than the Soviet era [2, p. 167]. The exception is significant, since recent research relocates the centres of early Caucasian carpet production westwards, closer to regions where historically there was an established Armenian presence. In any event, both positions appear to reflect a point of view first articulated nearly a century ago by Arthur Upham Pope. According to Pope, "there is no record nor even local tradition that rug weaving was ever carried on in Armenia to any extent", and to prove that his views do "not rest on negative criticism only", he cites "one genuine Armenian carpet in existence which holds true to Armenian style' in the collection of a certain Wilhelm Holzman in Berlin" [3, 152].

Pope's shoddy scholarship here is underlined by the fact that his conclusion is based on the specious principle that the absence of evidence is evidence of absence. Even the singular "genuine" Armenian carpet cited is incorrectly attributed as recent research has shown that its in-woven inscription "is not in Armenian, and the 'devices' used in it have no resemblance to illuminations in Armenian manuscripts. All the letters around the border are in Slavonic and Georgian" [4, p. 233]. Neressian provides other examples of mis-identification, many owing to the common practice among Armenian craftsmen of concealing their signatures within the textiles' design elements.

It is unremarkable that textiles of whatever weaving technique have not survived from the period of the Armenian kingdom or from later epochs when Armenians were subservient to invaders from outside the region. There is, however, evidence that carpets were woven in the Caucasus as early as the 7 th century BCE. In this regard among the grave goods described in connection with a Neo-Assyrian royal burial is a "rug with a black border" made in Urartu [5, p. 5). It is widely accepted that Armenians were the social and political heirs of the Urartian kingdom but the important point here is that carpet weaving was established in the Armenian Highlands well before there is evidence of the craft being practiced elsewhere. Xenophon, for example, writing in the first quarter of the 4th century BCE, provides the first literary reference to Persian carpets (Anabasis vii:3:18; vii:27), while the Pazyryk carpet, the earliest surviving intact piled carpet, attributed by many to Persia and others to Armenia, $[6$, p. $5 ; 7$, p. 46$]$, is now dated to the late 4 th or 3rd century BCE. If anything, the Neo-Assyrian cuneiform tablet adds verisimilitude to claims of an Armenian rather than to a Persian origin.

It is clear that from ancient times the Armenians continued to inhabit their traditional homeland, remained largely Christian, and engaged in global commerce. They lived in villages and cities and were known to weave carpets. Villagers presumably produced carpets mainly for personal consumption, while those living in cities would have woven both for their own use and commercially. Beyond that little else is known of the nature of production, the designs woven, or whether weaving was practised by all the inhabitants of the Caucasus. Even this perspective is too facile: it would be wrong to regard the weavings of Armenian or Greek Christian converts, as undoubtedly occurred, as Islamic when almost certainly their output would have continued to be imbued with their ancestral cultural traditions.

The simple fact is that of all the major population groups that inhabit the Caucasus the Armenians have the longest connection with the region, and are the only ones reported by both ancient and medieval chroniclers as being skilled dyers and weavers. It is inconceivable that Armenians did not historically weave carpets or contribute to the region's common design pool. Indeed, literary sources attest to the fact that Armenians wove carpets from very early times, and continued to do so even 
as late as the last quarter of the 15th century. In a Persian manuscript entitled History of Isfahan the author, Husain b. Muhammad al-'Alawi, reports that the city's bazaars are "filled with the produce of every clime" after which follows a list of places and their exports, including "carpets and rugs from Armenia" [8, p. 434]. Even so, the earliest extant Caucasian piled weavings, the so-called Dragon carpets (Figure 1), date only from the 16th century and as things presently stand there is considerable disagreement as to whether they are indigenous or imported from Safavid Persia.

For early Caucasian carpets, common practice is to classify them on the basis of their designs. For later weavings "a geographic terminology has evolved, out of the experience of the early carpet trade, which classified rugs into regions according to a combination of design types, and structure features (including length and density of pile and wool quality) with a sub-classification based on the association of certain rug designs with specific towns and villages" [9, p. 96]. Neither approach is satisfactory, the former an admission of an inability to identify objective criteria enabling an agreed attribution, the latter because the classification depends on dealer lore, to use Brian Spooner's phrase, where commercial motives would be expected to dominate detached scholarship [10].

\section{Literature review}

For many authors, the starting point for their research is the assumption that owing to the mixture of cultures and religions in the region, it probably will never be possible to disentangle the contribution of any particular group [11, p. 28]. They are thus free to introduce additional "controls", often masquerading as conventional wisdom, from which they derive their conclusions.

\footnotetext{
[With regard to this class of carpet] we are dealing with weavings from Transcaucasus which have been worked out within the scope of the same factors which have always determined the course of the knotting art in the Near East, be the weavers Christian or Mohammedan. The technique may well have been disseminated as a home industry through the Caucasus area quite early by Turkish tribes and practiced also by Armenians from time to time, without there having been able to influence the stylistic trend. However, whether knotted rugs were specifically meant by the Armenian carpets of some Early Medieval sources is more than questionable; it is much more likely that by this expression were signified the products of the many older weaving methods which have proved outstandingly successful in this very ArmenoCaucasian region, and among which individual techniques such as the Sumak and the Sile had perhaps already been perfected many centuries before. A more precise delineation of the neighbourhood in which these 'Dragon carpets' originated is not possible at this time; reminiscences of their classical phase survive in various categories of Caucasian weavings [...] until well into the 19th century [12, pp. 66-67].
}

Conservar Património 31 (2019)

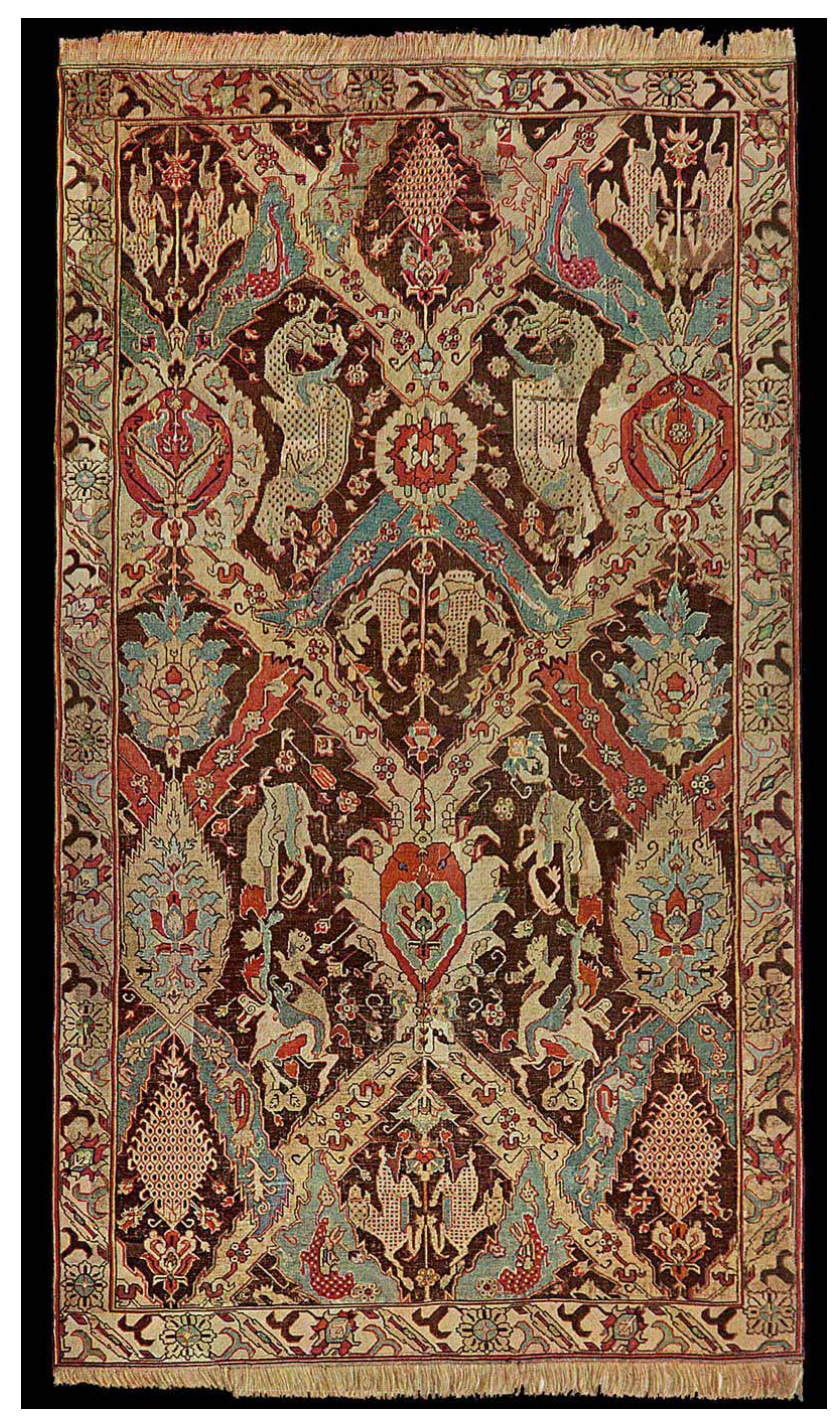

Figure 1. Dragon carpet, Armenian or Northwest Persian carpet, 17th century (V\&A Museum, London).

Note, in particular, some of the key assumptions embedded in the above argument. The knotting technique is rejected as being indigenous to the region, having instead been introduced "quite early" by invading Turkmen tribes, and practiced only "from time to time" by Armenians. It logically follows that if knotted pile rugs did not feature in the pre-Turkic Caucasus, early sources that mention carpets were obviously misunderstood: the rugs thus referred to were more likely to be those woven using "older weaving methods", such as the two specifically mentioned - Sumak and Silé - both flat woven textiles. Armenians undoubtedly wove pile-less carpets but which, then as now, were intended mainly for personal use; piled carpets, by contrast, were woven primarily for sale. Once these assumptions are relaxed, Bode and Kühnel's argument collapses. By reversing their assumptions, that is, making Armenian weaving practices and traditions anterior to the Turkmen invasions, it would be possible to determine not only "the neighbourhood" in which these carpets were made but also who wove them. 
This approach is closer to that adopted by Kendrick and Tattersall. What is especially noteworthy about their perspective is that in an earlier publication Kendrick anticipated Bode and Kühnel's discussion of the difficulty involved in sorting out individual weaving traditions in a multi-ethnic environment: "The chief drawback to the classification [of such rugs] is that characteristics of more than one district are not infrequently combined in a single carpet, and moreover, the tendency of modern times has been towards the effacement of local peculiarities" [13].

The Armenians were skilled carpet weavers. A race in subjugation, scattered as they were, probably copied the style of districts where they worked. There is a type of design which began to be associated with Armenia twenty years ago, when a carpet with a long Armenian inscription of the 17th century was offered on sale to the $[V \& A]$ Museum. The nature of the description alone is not decisive as to the nationality of the craftsman, but the design in this case was distinctive, and there was nothing in its character which argued against a location in the region comprising Armenia, North-West Persia, and the Southern Caucasus. Carpets of the type were probably made in all these districts, but there are advantages to grouping them together as Armenian in origin, and that designation is as near as we can get [14, p. 9].

Without Bode and Kühnel's additional questionable assumptions, others, too, had little hesitation linking Dragon carpets with both Persia and Armenia. For example, Willhelm Valentiner, then-Curator of Decorative Arts, Metropolitan Museum of Arts (New York) had no difficulty ascribing these rugs to Armenian weavers, concluding that Dragon carpets were woven in a production centre "influenced by Persian art, such as was the case with Armenia. Moreover the purple kirmiz, which is a colour commonly occurring in these rugs, has always been a favourite dye of Armenian weavers since earliest times. [...] These rugs were imitated in Armenia down to the eighteenth century, but always with small changes in the patterns, especially in the border designs, and with the introduction of more modern decorative motifs" $[15$, p. x]. Later curators from the same museum reached the identical conclusion. Writing more than a decade later, Breck and Morris, aver that "[a]lthough the influence of Persian models may be discerned in the use of animal motives in the compositional scheme, these carpets are not the work of the skilled Persian weavers. They come in all probability form the looms of a peasant or nomad people [...] [it is] now generally accepted that the home of the 'dragon' rugs is Armenia” [16, p. xxii].

The debate continued into the 1920s and beyond. To be sure, the findings of some studies are more compelling than others, although none have significantly altered the terms of the debate. Indeed, some scholars have gone so far as to assert that because such inscriptions and other Armenian references are all posterior to the earliest Dragon carpets must belie the latter's Armenian origin. The logic of this position, as with Pope's conclusion cited above, is premised on the dubious principle that the absence of evidence is evidence of absence; other scholars, by contrast, sought out examples that based upon structural and aesthetic considerations would affirm the continuing relevance of an Armenian attribution.

Kendrick, for example, in his 1929 article [17, pp. 1516] sought to extend the range of Armenian weavings beyond the Dragon carpet, discussing two examples then being exhibited at a private gallery in central London, neither of which could be regarded as Dragon carpets but which bear many of their characteristic features (Figures 2a and 2b). Whether derivative (as many scholars claimed) or not, if these carpets could be shown to be of Armenian provenance it would tend to reinforce the traditional attribution of Dragon carpets to Armenian weavers. Kendrick's ascription is based in part on the fact the design of early southern Caucasian carpets often included small crosses and thus indicative of a Christian origin, an interpretation anticipated by Sakisian [18, p. 254], who in connection with one of two Armenian carpets acquired by the Turkish and Islamic Arts Museum in Istanbul detected that at its bottom end there were four crosses, "preuve évidente de fabrication chrétienne et, dans l'espéce, arménienne".

On their own, of course, these cruciform ornaments carry no diagnostic weight; it is only when combined with other characteristics, Armenian inscriptions or dates based on the Armenian calendar or, even Gregorian dates, for example, does their probative value increase. The two carpets studied by Kendrick contain ornamental crosses, which together with two other characteristics namely, the region in which they were made coincides "with districts bordering on the present-day republic of Armenia", and their design includes the introduction of "crude and diminutive forms of animals" that are familiar characteristics of so-called Kazak rugs - that collectively support an Armenian attribution. In contrast, Kendrick elides the issue of the carpets' dates. The question of the age of an Armenian carpet is not always an easy one. The archaic forms may carry undue weight. In these two examples there are features comparable with some inscribed and dated carpets such as the well-known Gohar carpet dated to 1679-80 (Figure 3).

In a much later study, Willborg [19] extended the geographic range of Armenian weavings, in this instance to southwest Asia Minor. His analysis focused on a group of carpets bearing a close resemblance to the Gohar carpet but which he labels Dragon carpets owing to having found what he regards as dragons incorporated into their designs, a feature not to be found in either the Gohar carpet or the two illustrated by Kendrick. Willborg concludes that his sample was probably woven in Anatolia, more specifically, the Gördes-Demirsi area. "The most likely producers were Armenian settlers from the Caucasus who brought with them the design idea, incorporated some Turkish elements, mostly in the borders, and transformed it all into very beautiful eye catching rugs". Without a known and dated Armenian prototype, the absence of evidence principle would seem to rule out their being of Armenian 

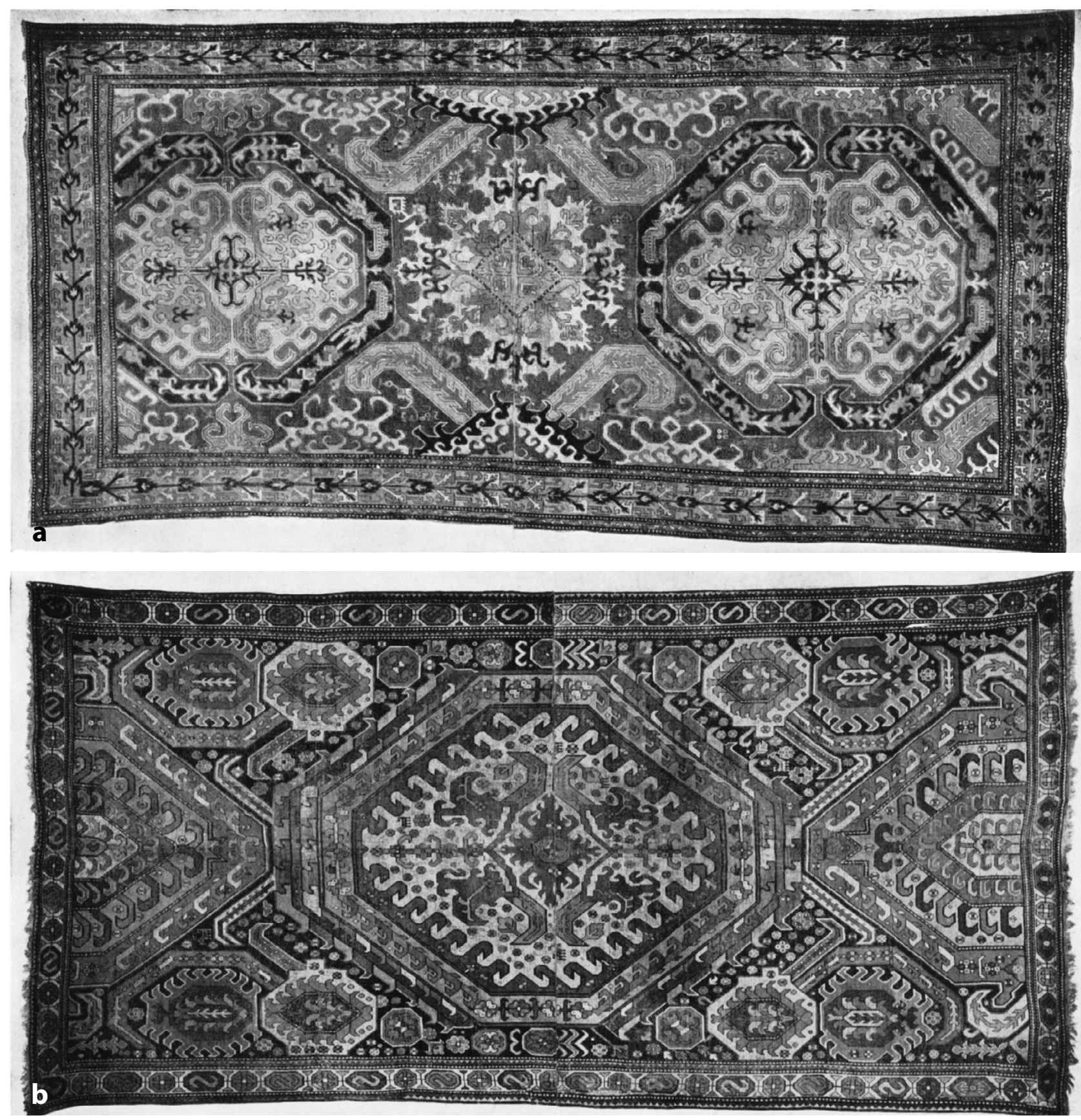

Figure 2. South Caucasus (Armenian?) carpets, 18th century (Jekyll's Ltd, London, UK).

manufacture, especially as their structural characteristics suggest an Anatolian provenance.

Finally, attempts have also been made to link design origins with a group of Safavid-style silk embroideries made in the Caucasus ostensibly by Armenian weavers. There are, to be sure, strong affinities between these Safavid-era embroideries and carpets woven, above all, in the Karabagh region. Although the connections are entirely plausible, in the first instance there is no precise way of determining the direction of causation. This fact, however, does not deter Franses from asserting the priority of the latter: "The knotted pile carpets of the 15th to 18th centuries are among the most obvious influences on both the long-stitch embroideries from that region and the tent cross-stitch embroideries [...] attribute[d] neighbouring Shamakhy region in Azerbaijan. There are also design connections between some 16th and 17th century embroideries and knotted pile carpets from northwest Iran" [20, p. 60]. A less contentious position would be to accept that both textile designs are contemporaneous, reflecting the fact both originated in royal workshops and thus drew upon a wide range of potential designs. Here, the Armenian attribution, although possible, appears less convincing, notwithstanding that the Karabagh region has long been recognised as falling within the Armenian cultural ambit. 


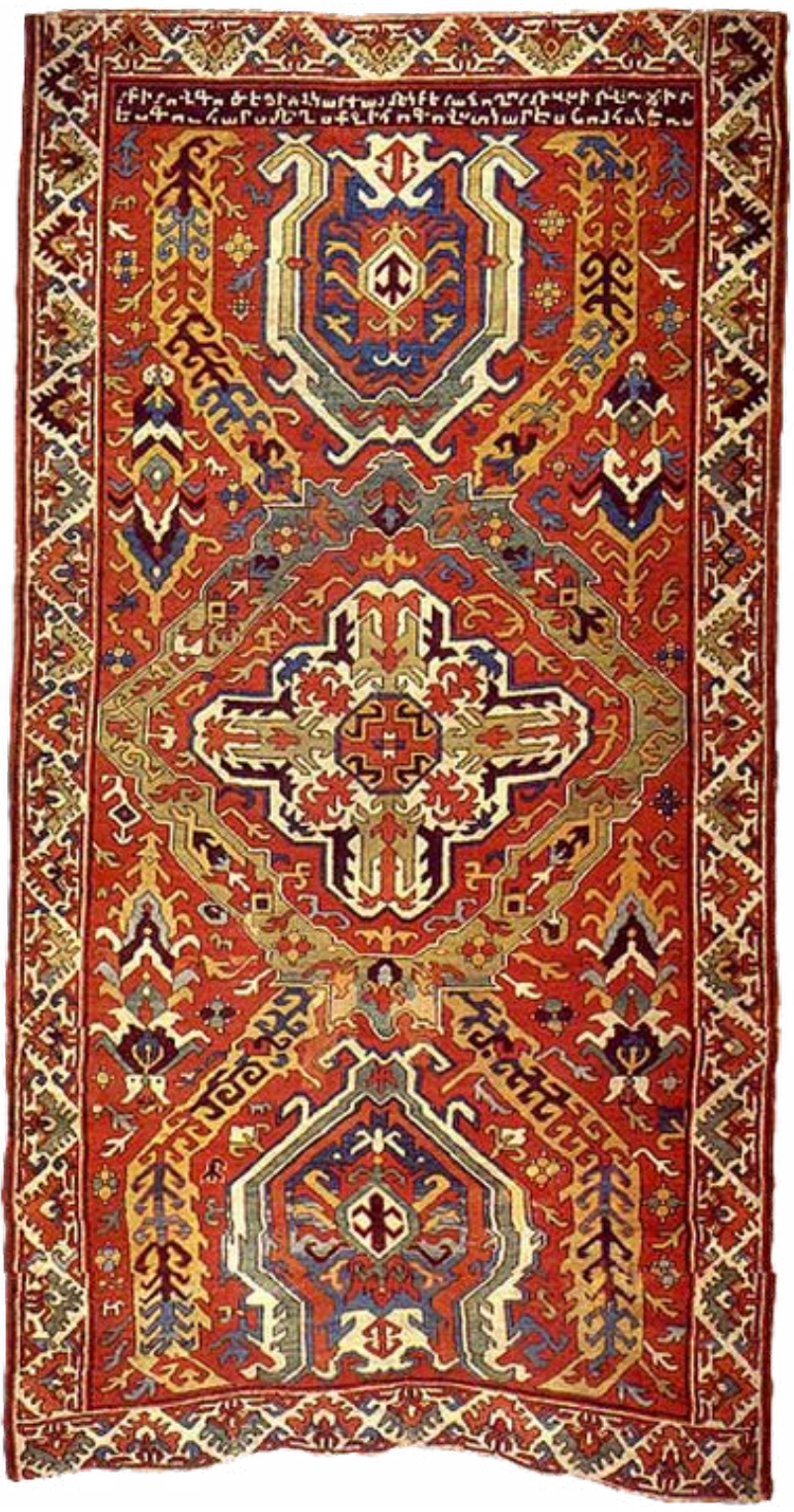

Figure 3. The Gohar rug (private USA collection).

The fact that workshop designers and weavers may have been Armenian carries little weight since the designs clearly reflect imperial rather than traditional aesthetic values. This conclusion is confirmed by an extremely fine 17 th century silk and metal thread embroidered carpet of the Polonaise type made in the reign of Shah Abbas (1588-1629) and signed with the name Yakob, written in uncials concealed in medallions, a practice often found on Armenian artefacts, its hidden position clearly confirms that it was made either in an Armenian workshop or by an Armenian craftsmen; other characters in Armenian script indicate that the carpet was made in 1619 [4, pp. 231-233, figs. 20-21]. On the other hand, it is possible that among provincial copies of these designs weavers may well have incorporated traditional motifs unique to the region's diverse population.

None of these arguments ended the debate, which persisted from that time to the present with both sides repris- ing old arguments, many devoid of historical, logical or empirical content. "There have probably been more misleading statements about Caucasian rugs than about any other major group, and anyone consulting more than one source is inviting a potent dose of inconsistency and fantasy. While there are surviving rugs thought by many to represent seventeenth and eighteenth-century weavings form the Caucasus, there is virtually no hard information until the late nineteenth century, when a local industry began turning out large numbers of rugs for the market" [21, p. 258].

\section{Alternative possibilities}

For present purposes our main interest lies in two issues that are central to the debate, that is, whether Dragon carpets have a unique structure so that they can confidently be assigned to a particular place or region even if, as of the present, it is not possible to identify who actually wove them, and the related issue of whether, as some authors have suggested, in-woven inscriptions provide a sound basis for establishing the ethnicity of the weavers. With respect to the first point, Franses and Pinner [8, p. 97] assert that "the construction of this group indicate they are from one weaving area if not from a single manufacturing centre, but while most known rugs in this family may with confidence be dated to the 18 th century, the dating of the earliest of its surviving members is controversial, opinions among scholars varying between the early 16 th to the late 17 th century. There is historical evidence of the weaving of carpets in the Caucasus some centuries earlier, but nothing is known of their designs".

Several issues raised by Franses and Pinner warrant additional comment. Consider first their assertion that Dragon rugs are so similar in terms of their construction that it is possible to assign them with a high degree of confidence to a particular geographic area, "if not from a single manufacturing area”. Not all scholars, however, are prepared to accept the structural uniformity assigned by the authors to these rugs. "Examination of a number of Dragon rugs clearly indicates the likelihood that they were not all woven in the same place. These may be grouped more meaningfully according to their colours, structure and, to a lesser extent, their designs" [22, p. 55].

Whether in-woven inscriptions provide information that can be used to infer ethnicity was pre-figured by Bode and Kühnel. Their comments refer to an inscription contained in a Dragon carpet in the collection of the Textile Museum (Washington, DC). The inscription, written in Arabic letters, bears the name Hussein Beg and a date variously read as 1001 or $1101 \mathrm{AH}$ (1592 or $1689 \mathrm{CE})$. The authors dismiss the later date, arguing that it is unconvincing as it provides "an improbably late dating", and proceed to argue that the inscription, coupled with the "unmistakably Islamic character of the [carpet's] decorative scheme", clearly "refute the idea that this type of carpet could have been made by an Armenian". As with 
their earlier discussion they claim too much while ignoring some obvious difficulties with their arguments. For one thing, the anomalous character of the carpet, above all, its unusual colouration, drawing and imposition of its central medallion on the latticework, and the fact that the palmettes are particularly degenerate [22, p. 60, fn. 12] has led some scholars to conclude it actually is a 19th century Kurdish recreation of a Dragon carpet [23], while others have noted that the "Arabic inscription is so atypical", that it reinforces the suspicion of it being a late copy.

And, finally, Franses and Pinner aver it is unclear where exactly these carpets were made or by whom; they note that Kuba, Armenia and eastern Turkey have all been mentioned as possible venues. However, on the assumption either of inertia or continuity of weaving traditions, they claim it may be possible to narrow the likely location of their manufacture by relating later carpets that closely resemble these earlier types in terms of structure, colouration or the ornaments that feature in their design. Applying this criterion, the authors attribute their production to the Karabagh region "often popularly included among 'Kazak' rugs”.

On this, like most others issues connected with Caucasian carpet origins, there is disagreement, although there seems to be a general consensus that owing to their size - the V\&A carpet illustrated above measures $350.5 \mathrm{~cm}$ $\times 195.6 \mathrm{~cm}(11.5$ feet $\times 6.4$ feet $)$, others are larger still - and other technical features they are more likely to have been woven in a town or city than in a village; in other words, they are almost certainly commercial products [2, p. 166]. Like Franses and Pinner, Eiland favours Karabagh, and the city of Shusha in particular, because "there is reason to believe the city has long been an Armenian centre" [22, p. 57]; Eiland's second and third choices are, respectively, Gendje and Shemakha.

There is some evidence indicating that weaving was carried out in the Karabagh region in the 16th century. Father Krusinski, a Jesuit priest who lived in Isfahan reported that Shah Abbas established royal workshops in, among other places, Shirvan and Karabagh, notably instructing the karkhana (workshop) in each province to "weave in its own manner" [24, p. 2431]. However, it is worth pointing out Father Krusinski resided in Persia c. a century after the royal edict was supposedly issued, and although his account is often repeated it has never been independently verified. If there was such an edict, the fact it commanded provincial workshops to weave in the local style would seem to favour the conclusion that Dragon carpets were regionally specific and thus unlikely to reflect court tastes.

Wright and Wertime, contrariwise, argue that "no case can be made for Shusha" as the source of the Dragon carpet. 'The southern part of Karabagh became a separate entity under Nader Shah. [...] Shusha dates back only as far as 1752 when its wall was completed; travellers who visited Shusha in the early 19th century all note its newness. It is a commonplace of Azerbaijan carpet history that Shusha constitutes the 'youngest school' of carpet- weaving. If the Dragon and related floral carpets came from the Shusha area, they would have been made in a rural setting, which is most improbable" [23, p. 26]. While many scholars agree with this conclusion, others claim that Shusha was founded well before then having been an ancient city and fortress in the Principality of Varanda - one of the five autonomous feudal states in historical Nagorno Karabakh - during the Middle Ages and through the 18 th century.

Eiland's second and third choices appear equally implausible. With respect to Gendje, even though it is an ancient city, founded in the 8th century CE, it was destroyed in the early 17 th century and relocated six kilometres to the southwest [25, p. 93]. And finally, it is true that Armenians appear to have inhabited many villages in the district, including Shemakha, in the vicinity of which were "many monasteries, and where their Bishop lived". There is, moreover, evidence of carpets being made in Shemakha during Safavid times. And while Armenian merchants appear to have been actively involved in this trade, is unclear whether those living in surrounding villages or in the city itself practiced the craft. However, by the early 18th century as a result of political and economic dislocations trade and manufacturing activity in Shemakha appears to have ceased [26, pp. 38, 116], and thus it, too, is an unlikely candidate for being a major centre for the production of Dragon carpets.

The latest proposed location for Dragon carpet origins is Tabriz, notwithstanding that no significant carpet weaving industry existed in the city, the region's capital, or its environs, until the 18th century. According to Wright and Wertime, "Persian sources of the time identify Tabriz as the location of a significant textile industry, including silk weaving. Tabriz was not however among the centres singled out for excellence in carpet production. [...] Carpets were made in Tabriz and its surrounding area between 1702 and 1735, as established by the independent comments of three knowledgeable Europeans" [23, p. 26]. Even if correct, we are asked to accept as reasonable an hypothesis asserting that a carpet with a design inspired by a 17 th century Persian prototype was made in a city or region that had no significant rug weaving industry at the time to which it is dated. There is, however, ample evidence that carpets were in fact made in Tabriz well before the 18th century, albeit not necessarily by Turks.

Given the objective of their research Wright and Wertime appear to have limited their focus to the period in which Dragon carpets were made, ignoring other evidence to the contrary as being irrelevant to their argument. However, from both a practical and historical standpoint whether, and when, carpets were woven in Tabriz is important. Continuity of weaving activity would quite obviously strengthen their argument; on the other hand, implicit in their discussion is that Tabrizi weavers were Turks. If, by contrast, it could be shown they were Armenians, Wright and Wertime's preferred location would not be affected, but it would subvert decades of research rejecting that possibility. 
The earliest European references stress Tabriz's commercial importance and highlight that the only manufacturing activity then carried on in the city was the production of silk and other luxury textiles, both themes common to the accounts of other Europeans who visited the city between the 13 th and 15 th centuries [27, p. 261]. It was not until the last quarter of the 15th century that the first European reference to carpet weaving in Tabriz is to be found. Giosafat Barbaro, the Venetian Ambassador to the Persian court, reported in 1473 that the most beautiful carpets, made with both wool and silk yarns, superior in fact to those made in either Cairo or Bursa, were woven there [28, pp. 59-60].

Islamic references to Tabriz are not only significantly earlier than European sources, but confirm that carpets were woven in the city. Ibn Hawqal, the Arab geographer, asserts that carpets were made in Tabriz in the 10th century, the context of his remarks suggesting that Armenians were responsible for their production. "There are made in Marand, Tabriz, Dabil, and the districts of Armenia, Armenian cushions (maka'id) and carpets (ankhakh) known as Armani mahfuir (Armenian carpets with a raised pattern), with scarcely an equal in any place which possesses manufactures resembling these" [29, p. 95]. All three cities are known to have an Armenian connection, the latter being the country's early medieval capital; indeed, Het'um of Corycus, the 13th century Armenian monk and historiographer, claims that Tauris/Tabriz once was part of Armenia [30, chapter 9, p. 14]. The 9th century Persian historian Baladhuri notes additionally that Azdisat, a place near Dabil, was known locally as "kirmiz village", kirmiz being an insect dye widely associated with Armenia [29, p. 95].

The continuing Armenian presence in the city is attested by Jean Baptiste Tavernier, the French gem trader, who made six voyages to Persia between 1630 and 1688, and later authors. Like his European predecessors, he highlights the fact that Tauris/Tabriz is the "mart for Turkie, Muscovy, the Indies and Persia. There are an infinite number of Merchants and vast quantities of all sorts of merchandise [...] Money trolls about in that place more than in any other part of Asia. Many Armenian Families have got great Estates there by Trade, and understand it better than the Persians". He then goes on to enumerate trades practiced in Tauris/Tabriz, but the only textile manufacture carried on in the city is silk weaving, there being more silk weavers "than of any other trade" [31, Book I;4, p. 20). The Armenian reference is noteworthy not only because it indicates that the silk trade, Tabriz's principal industry, was in their hands but also because it confirms their long association with the city.

The same observations are made by John Bell, one of the three "knowledgeable Europeans" cited by Wright and Wertime, who visited the city in 1716. Like his predecessors, he reports that Tabriz had a "considerable commerce in raw-silk, and manufactures of carpets, and silk and cotton stuffs", and that many of its inhabitants were Armenians [32, p. 79]. We are so conditioned to regard Armenians as merchants or traders, the possibility they too may have woven carpets is not even considered, notwithstanding that Wright and Wertime provide evidence that Armenians did make carpets in the Caucasus, and at an earlier date than those reputedly made in Tabriz.

In this latter connection, Wright and Wertime cite Master John Cartwright, a missionary who travelled through Syria and Persia at the beginning of the 17th century, to the effect that Armenians at that time wove carpets in Chiufal (Julfa), Azerbaijan. "At Chiufal we stayed eight days and passed again the River Araxis, leaving the noble kingdom of Armenia, called now Turcomania, because of the Turcomans, a people that came out of Scythia [...] who live as shepherds in their Tents, but the native people (i.e., the Armenians) give themselves to husbandry and other manual sciences as working of Carpets and fine Chamlets" [33, p. 498].

Cartwright's observations establish several important points: the Turkmen were pastoralists, and apparently did not practice weaving or at least there is no mention of their having done so. It seems reasonable to suppose, therefore, the wool from their flocks was sold, most likely to Armenians who, Cartwright reports, did weave carpets and other textiles, while the reference to Julfa establishes that weaving was an urban craft in the Caucasus. He describes the city as being inhabited by "Christians, partly Armenians and partly Georgians; the people rather given to traffic in Silks and other wares whereby it waxes rich and full of money [...] This Town consists of two thousand homes and ten thousand souls" [33, p. 496]. Cartwright's views on both the number of houses and the ethnic composition of the city's Christian population have been challenged, the current view being there were fewer inhabitants and Armenians were its only Christian residents [34, pp. 44-45], and thus the only Christian weavers in the city.

Shortly after Cartwright's visit Shah Abbas, being unable to defend the territory along the Aras River, ordered the evacuation of the town, which was destroyed to prevent the local population and its wealth from falling into the hands of the Ottomans. The residents were forcibly relocated to New Julfa, near Isfahan where, it is claimed, "they worked not as weavers, but as factors for the silk trade and as craftsmen; tombstones indicate that these craftsmen may have included a small number of carpet weavers" [23, p. 20]. It seems very odd that virtually all the relocated inhabitants of the old city, to which must be added Armenians later expelled from Isfahan by Shah Abbas II between 1655 and 1659, suddenly ceased practicing a traditional craft - all the more inexplicable given that carpet weaving was one of a small number of sectors of the Safavid economy with favourable commercial prospects - the sole proof for which is the absence of any reference by 17th century European writers to carpet weaving in the new city.

Despite differences of opinion over the origins of Dragon carpets, and where they were made, there seems 
to be a fairly broad acceptance of the fact that Armenians wove piled carpets around the time these carpets make their first appearance, a conclusion endorsed by an earlier generation of distinguished scholars such as Kurt Erdmann and Maurice Dimand, though neither was willing to go beyond that concession; on the question of origins they and others looked elsewhere.

Erdmann, for example, dismisses an Armenian origin on the grounds that Dragon carpets were made after the Armenian kingdom ceased to exist and "the primitive robustness which distinguishes Dragon carpets cannot be attributed [to Armenians] because it is characteristic of the Caucasus in general" [35, p. 153]. Erdmann's comments are not especially compelling as neither of the two reasons cited for dismissing an Armenian origin are convincing. The fact that all extant Dragon carpets are dated to the period after the demise of the Armenian kingdom does not preclude the possibility they, or their precursors, were woven while the kingdom still existed. The significance of their "primitive robustness" as being "characteristic" of Caucasian weavings is equally questionable. Given that Armenians were native to the Caucasus would suggest, contrariwise, that at minimum they contributed to the common design pool or, as others believe, such designs derived principally from Armenian (and Greek) originals.

Dimand, by contrast, is more receptive to an Armenian attribution. Once updated to incorporate later research, his analysis provides even stronger confirmation for that conclusion, notwithstanding his principal motivation was to reconcile competing views on Dragon carpet origins. In agreement with then-existing scholarship, Dimand located the centre of their production in the Kuba region of the eastern Caucasus (that is, Azerbaijan), but conceded that Dragon rugs could have woven by Armenians - and thus likely to have been imbued with the characteristics of their homeland - but with the important caveat that when discussing an Armenian rug what matters is not the geographic location of their manufacture but rather the nationality of the weaver. "Actually the [Armenian and Turkish] attributions are not mutually exclusive if one uses the term 'Armenian' nationally rather than geographically. Armenians dwell in the Kuba region and it is not impossible that they, as well as the Turks, who were also at home in this region, produced such rugs. Caucasian rugs with Armenian inscriptions are known; for example, the floral rug, related to the Dragon rugs, that bears the name of its maker, Guhar, and the date 1679. On the other hand, the late 17th century dragon rug in the Textile Museum bearing the date 1101 (October 1689) and the name of its owner, Husain Beg, has its inscription in Turkish" [36, pp. 266-267]. It is now widely accepted, as noted above, that the Turkish exemplar cited by Dimand to support his argument that Dragon carpets were also woven by Turks was, on the basis of stylistic and other criteria, made instead by Kurds and much later than indicated by its in-woven date.

Dimand's revised analysis provides strong support for Armenian production of Dragon carpets, with the implicit corollary that by incorporating traditional Armenian designs and motifs an indigenous origin is indicated. Others, by contrast, reject such an interpretation insisting instead that such designs must have been imported from outside the region. Turkey has been identified as one such source, a possibility dismissed by Pope who regarded the Turkish contribution as insignificant, insisting instead that whatever merit they may have managed to achieve was due entirely to their contact with the more highly civilised Persians. "The Seljuks and Ottomans might almost be called a cultural extension of Persia. When the Turks swept into Persia they were hardly more than barbarians, but in both literature and the arts they were soon eager pupils of Persian Masters, and from the twelfth century on in the Turkish art of Asia Minor is almost completely under the dominance of Persian ideas and methods" [37, p. 237]. The other, and more widely accepted possibility, is Persia: but if so, how then to explain the transformation from the sophisticated curvilinear designs of Safavid carpets to the coarsely woven, geometric ("primitive") patterns characteristic of Caucasian weaves?

Charles Grant Ellis [38] also regards Dragon carpets as deriving from Persian prototypes originally woven in Kerman in the early 17 th century; the fact that many were discovered in Anatolian mosques - but not, significantly, in the mosques of Tabriz from where some claim they originated - explained possibly by the fact their highly abstracted designs were meant to accommodate (Sunni) Muslim religious susceptibilities that proscribe the depiction of living beings or, perhaps, in view of thenongoing tensions between the Ottomans and Safavids, to disguise their Persian origin. A far simpler explanation was proposed thirty years earlier by A. U. Pope. "Nearly all the important Persian carpets were known and copied there (Eastern and Southern Caucasus region) [...] For the most part the technique was very coarse, so that the fluid designs of the originals took on a certain geometrical rigidity and angularity of outline, but this gave the finest of them, such as the Dragon carpets, an emphatic, challenging force. The weavers, who for the most part, worked without cartoons, as is shown by an analysis of the carpets themselves, contributed a good deal of their own native style, particularly in the rich and intense colour schemes which are distinctly different from the Persian prototypes" [37, pp. 141-142].

\section{A comedy of errors?}

Pope concluded that these carpets were made in "Kuba and in some of the surrounding villages principally in the seventeenth century, with somewhat coarsened derivatives in the eighteenth century. By a strange comedy of errors these were, for a long time, thought to be Armenian, a view that has now been generally given up" [37, p. 141-42]. "No weavings of the entire Orient compare in monumental grandeur with these mysterious carpets. Woven probably by tribes of Mongolian descent that drift- 
ed into the Caucasus in the thirteenth century they retain from their barbarian origin a strong quality of primitive force" [30, p. 169]. The "comedy of errors" referred to by Pope was elaborated upon in an previous paper [3] that attracted, and continues to attract, critical responses $[4,18$, 39-41] for Pope's response to the first of these.

Few, if any, carpets survive from the Timurid era and thus it is impossible to know anything of their structure or designs. Historians have inferred their appearance mainly from illustrated manuscripts, a practice that has been described as "questionable at best", with the surviving parallels for the depiction of rugs in 15th-century Persian painting usually turning out to be Anatolian [42]. Nor is Pope's Kuba attribution acceptable any longer as the town developed only in the late 18th century, while carpets formerly attributed to eastern Daghestan have now been reassigned to the south and west in the urban centres of Karabagh (Shusha) and Shirvan (Shemakha). Karabagh, as noted, contained large numbers of Armenians; their presence was more modest in Shirvan [43, p. 6], although Lynch reports they "were numerous in the town and district" of Shemakha [44, p. 449]. Finally, Muslims accounted for 93 per cent of Shirvan's population, more or less equally divided between sedentary and nomadic families, with half the Muslim population consisting of Kurds [45, p. 195]. Long known for their weaving skills, it is possible that many of the carpets attributed to Turks may in fact have been woven by Kurds.

For other scholars temporal, technical and geographic considerations similarly argue against an Armenian origin. Bell, for example, anticipated Pope's argument that there was no basis for connecting Dragon carpets with Armenia, insisting that its history and geography made it an unsuitable candidate. "Throughout the Middle Ages [Armenia] was broken up into a number of petty kingdoms alternately subject to Byzantium or Persia, Arabs or Turks, and then for brief intervals free. Kurds and Mongols periodically harried these, and even the annexation of the whole country to the empire of the Osmanli Turks brought no cessation of disturbance. Under such circumstances it would be rather remarkable if, despite their position, favourable to the receipt of influences from Persia, the Caucasus and Byzantium, the Armenians had developed any marked style of art. They certainly have not in any other material and it is therefore permissible to doubt if they did in carpet weaving" [46, p. 10].

For Erdmann, it was the Turkmen of the steppe that first introduced piled carpets into the region which perforce means Armenians could not have practiced the craft before then. That, of course, says nothing about the nature of pre-invasion designs: even if it is conceded that Armenians did not originally weave piled carpets there is nothing to prevent them from having subsequently translated their traditional designs from one medium to another. After all, it is not unknown for weavers to transpose flatweave patterns on to piled carpets; the fact that Caucasian designs are distinctive and predominantly geometric lends additional support to the hypothesis.
For Bode and Kühnel, as noted above, Armenian production was confined to flatweaves, that is, textiles meant for personal use, thus reversing the accepted relationship that regards flat woven (pile-less) rugs as the product of nomadic looms and piled carpets the output of sedentary weavers. The fact is most pastoral nomads do not weave pile carpets for their own use. They take too long to complete, are too heavy to carry and thus unsuited to the tasks for which they were purportedly made; moreover, because their looms must be taken apart for transport the size of the carpet that can be woven is limited. Instead, nomads weave flat woven rugs which avoid all of these problems. The sole exceptions are small weavings, bags meant to carry household utensils, such as spoons, or commodities, salt, for example, or as panniers, saddle-rugs or other animal trappings [47].

The direction of causality has, not unexpectedly, been questioned. Azadi, for example, expresses the view that the "European assumption that an art form is generally developed in an ecclesiastical or courtly environment and then imitated with varying degrees of simplification and misunderstanding in more popular settings cannot, however, be applied to study of Persian carpets". In fact, the carpet "was not introduced as a courtly art but was evolved among nomadic peoples at an early date" [48]. The main difficulty with Azadi's argument is that it reverses what is known about the nature of nomadic contact with more advanced urban communities. As Spooner reminds us "from what we know of the cultures of nomadic populations we should not expect them to develop more complex technologies than nearby settled populations [...] There is ample evidence to suggest that nomadic pastoralism throughout the Mediterranean, Mesopotamia and central Asia is culturally derivative of settled life, both in origins and continued interaction" [9, p. 211].

Inevitably, attempts have been made to reconcile these conflicting views. The contribution of different ethnicities or religions has been characterised by Denny as "style in place" or "style in race" and, while the thrust of his argument refers to Anatolia, it could just as easily apply to the Caucasus as the main protagonists were the same in both regions. "Style in place" stresses the importance of pre-Turkish (Greek, Roman, Byzantine and Armenian) influences, while "style in race" refers to the traditions brought by the early 12th century Turkic invaders, including "echoes" of the Islamic influences acquired in Persia and Central Asia. Denny's argument is that these are in reality false distinctions, favouring instead a more syncretistic interpretation that argues for "the important but not exclusive role of the importation [...] of artistic ideas by nomadic tribal Turkic peoples" [49, p. 16].

Possibly, but the more relevant art historical issue is the relative importance of the two ethnographic strands. The impact of Armenians on the textile arts, carpets included, was pervasive throughout the Near East, a conclusion attested by numerous references in early Islamic sources [29]. The evidence for the impact of the Turkish invaders 
is more equivocal: there are few if any carpets that can be securely dated before the 15th century; even among those that are so classified, there is disagreement as to whether they are the products of Turkish or Armenian looms [40].

If correct, the idea that the Caucasian weaving tradition prior to the Turkic invasions was uniquely one of flat woven carpets would have to be rejected. In which case, "most of the crafts of village life with the exception of certain techniques of animal husbandry must have been learnt by the newcomers from the native inhabitants" [ 50 , p. 27]. The nomad

is a cultural satellite of agricultural settlements, markets and cities, because he needs grain - more than he can grow himself, even if he does cultivate some. There is no independent nomadic cultural tradition. At times of political success the nomad apes the political institutions of the cities. [...] Not even pastoralism is a monopoly of nomads. In fact, the most significant cultural criterion for a general definition of the term "nomad" is ideological: a man is a nomad because he says he is. The primary function of this ideology would seem to be that it distinguishes its followers from the inhabitants of villages and cities and gives them an identity that they do not otherwise have [51, p. 261].

In short, the newcomers must have learnt commercial weaving from the pre-Turkic Christian population, mainly Greeks and Armenians, who from various European and Islamic accounts were known to have practiced the craft from very ancient times. In this connection there is evidence that silk textiles - "some [of which] were plain, others figured or cloths of gold, with designs similar to those of 'Tartar" - produced from the 13th century onwards in Tarsus, in Cilician Armenia were usually described in European inventories as pannus tarsicus, pannus de Tarsico, de Tars', or de Tarsen, but could also be listed as de opera de Turky (1315) or as de pann de Tarsen \& Turky (1311-1333): "[i]t is obvious that in these cases Turkey stands for Asia Minor" [52, p. 233]. It should thus be clear the descriptor Turkish or Turk should not automatically be taken to refer uniquely to Seljuks or Ottomans.

For a long time thereafter, non-Muslims constituted a majority of the population in Anatolia and the Caucasus. Even where the indigenous population converted, undoubtedly a significant input into the Islamisation of the region, there is no reason to suppose they abandoned traditional values; the fact that many villages converted en masse would tend to reinforce cultural continuity. "Just as in the northern zone of peripheral mountains there still exist whole districts of which the inhabitants have adopted the Mohammedan religion, but retain their affinity to the Greek race to which they belong, so within the statistical tableland of among the ranks of Mussulmans may be found considerable aggregates of people, who although of Armenian origin, profess the dominant creed" [43, p. 417]. It is thus arguable whether a distinctive Islamic patrimony existed. With regard to Asia Minor, "the Ottoman state adopted so much from the Byzantine Empire that it supplanted in Anatolia (even appointing some court personnel), that the Ottoman hybrid incorporated much of Byzantine and pre-Anatolian culture" [53, p. 73].

The Caucasus is unlikely to have been an exception, though wedged between the Ottoman and Safavid empires local inhabitants were exposed to two distinctive artistic traditions. It seems reasonable to assume that carpets intended for personal use or barter continued to reflect traditional designs, which are unlikely to have remained completely unaffected by new artistic currents; commercial products, by contrast, would almost certainly reflect patterns favoured by the market, whichever direction they emanated from. Unfortunately, too little is known about the extent of commercial production in pre-19th century Caucasia. It is virtually axiomatic that carpet weaving there was largely cottage based, both historically and in the 19th century when they first began to appear in large numbers in Western markets. The bulk of the region's population, Armenians included, were peasants living mainly in villages [54, p. 68]. Carpet workshops, whether extensions of home based production or independently organised, existed in many of the region's towns and commercial centres. By then official initiatives were introduced to enhance their commercial acceptability, which undoubtedly affected both their character and appearance, the extent to which is still being debated.

The best evidence favouring this perspective was provided centuries ago by Marco Polo, who reported that the "finest and most beautifully coloured carpets in the world" (et ibi fiunt soriani et tapeti pulchriores de mundo et pulchrioris coloris) were made in central Anatolia by Greeks and Armenians, "who reside in the cities [...] and gain their living by commerce and manufacturing" [55, chapter 3]. The specific geographic context within which Marco's remarks were set was Turkomania, which Yule identifies as embracing "a great part of Asia Minor [but especially] the decaying Seljukian monarchy, usually then called Rum, as the Ottoman Empire is now" [55, p. 40]. It is, however, clear from Marco's account that Turkomania covers a much a more restricted area. For one thing, from the way his chapters are arranged, Turkomania is situated between Lesser [55, chapter 2] and Greater Armenia [55, chapter 4]. It is thus to be located in an area corresponding to the six eastern Ottoman provinces that later formed Turkish Armenia. Moreover, it is clear from Marco's use of the term that Turkmen was meant to distinguish pastoral nomads from sedentary Turks, confirmed by the fact that he begins his narrative by noting that the Turkmen "dwell among mountains and downs where they find good pasture, for their occupation is cattle-keeping. Excellent horses [...] are reared in their country, and also very valuable mules".

This distinction was widely accepted among Marco's European contemporaries, for whom the descriptor "Turkmen" was invariably used to describe pastoral nomads, in contrast to "Turk", which equally consistently 
referred to the settled rural and urban population of Anatolia. For William of Tyre, for example, "there may be some distinction, at least in name, between those who made themselves a king, and thus achieved such glory, and those who still abide in their primitive barbarism and adhere to their old way of life, the former are nowadays termed Turks, the latter by their old name of Turkomans" [55, Book I, Chaper 2] The distinction, furthermore, persisted over many generations:

Another part of Armenia, which belongs only to the Turks, is inhabited by Turkmen, who gave it their name. Tartars, and going further back, those of Hun origin, lived in the Turkmen region of Tartary, which they left in the 11th century seeking other lands. After departing, some established themselves in the western part of Greater Armenia, along the length of the Euphrates River, to which they gave their name. They became subjects of the Turks, who gave them only the shadow of liberty. They continue to occupy the most beautiful countryside along the Euphrates, where they live in almost exactly the same way as when they first established themselves there. Although the governance arrangements, manners and customs of the Turkmen differ from those of the Armenians, they could truly be considered only a sub-division of Armenia [56, p. 4]

It is thus clear that Marco understood Turkomania to be the land that formed the western part of the Greater Armenian kingdom much of which had been reduced to pasture where nomad herds grazed. Only three types of herded animals are noted by Marco, cattle, horses and mules; there is no mention of sheep, as would be expected if Turkmen were responsible for introducing carpet weaving into Asia Minor. Moreover, since antiquity the region around Konya in antiquity was known to have produced wool [57, p. 235].

What appears to have changed in the Seljuk era was the scale on which pastoralism was practiced. While such actions were designed to perpetuate the State, they clearly were inimical to the growth of commerce and other mercantile activity [58, p. 77), which although curtailed remained primarily (or exclusively) in the hands of the indigenous population who continued to live in the region's former great cities where, among other things, they continued to weave carpets. The fact that Marco makes no mention of carpet weaving among the pastoral nomads would seem to confirm that it was then regarded as an urban occupation confined to the Greeks and Armenians then living there.

There is, finally, the possibility that a design dating from this era may have been incorporated in a fresco panel The Christmas Mass at Greccio painted by Giotto in the Basilica of St Francis in Assisi. Brüggemann [59, pp. 379-drawing 2, 390] maintains the carpet's eight pointed design depicted in Giotto's panel "could in fact be one of the handful of Rum-Seljuk carpet patterns which we would have to classify as being older then the venerable carpets found from Konya and Beyssehir", the latter regarded by some as among the oldest surviving examples of Turkish weaving. There is, however, the (unsupported) assumption that these designs must be of Turkish origin; the possibility they may have been adapted from indigenous (that is, Greek or Armenian) patterns is never considered, notwithstanding that would appear to be the more likely option.

\section{Conclusion}

Armenians are among the Caucasus' oldest inhabitants and the only ones to have a long tradition of dyeing and weaving carpets, while literary evidence from both Islamic and Western sources attests to their very high quality. By the late Middle Ages, Armenia - no longer an independent polity inhabiting a geographic backwater contested by the then-leading imperial powers - was of no further concern either to Islamic or European observers. It is unsurprising therefore that from the 16th century onwards there are only a few scattered comments as to their dyeing or weaving skills. European references, where they occurred, were confined more or less exclusively to their being merchants and traders and to their commercial acumen, ignoring all other aspects of Armenian economic and social life. The reality of course is that the majority of Armenians continued to reside in villages and like their regional neighbours practiced handicraft production that expressed their cultural heritage; Armenians, however, were the only ones known to have excelled at carpet weaving. A final point is that over the centuries many Armenians for various reasons converted to Islam, albeit without abandoning their cultural identity. In this way it is possible to grasp how many Armenian aesthetic values became part of the regional design repertoire.

Only following the Russian annexation of the Caucasus did foreign interest in the region revive, while the rapid increase in Caucasian carpet exports in the last quarter of the 19th century led to growing Western interest in the carpets themselves and by extension those who wove them. Much of the resulting information was supplied by dealers whose interest in promoting an understanding of the "uniqueness" of regional production was dictated more by commercial than ethnographic considerations, a phenomenon described as "dealer lore" and analysed in detail by Brian Spooner [9]. Caucasian carpets, with their bold geometric designs and bright colouration, employing traditional dyes and dyeing methods, added to their allure, notwithstanding that production was increasingly influenced by marketing considerations mediated through kustar (cottage industry worker) committees dominated and financed by the Imperial Russian government; official support for the 110 peasant workshops and schools totalled 1.53 million roubles in 1912 [60, p. 53].

The connections between historic and contemporary carpet production are, accordingly, tenuous at best. Little is known of the pre-Russian carpet industry, the earliest extant example of Caucasian production, the so-called Dragon Carpets, dates to the 16 th -17 th century. While 
many carpets of this design are known few are dated and typically lack in-woven signatures or inscriptions. Originally ascribed confidently to Armenian weavers, later authors concluded they could only be of Turkish or Persian origin, but even then opinion was divided, as today, as to which was the design's original home. The well documented association of Armenians with carpet production was discounted - owing either to the lack of "genuine" early examples of their work (pace Pope) [3] or, more recently, because they could only have been made in a well-capitalised court workshop, which at the time did not exist anywhere in the Caucasus (pace Bier) [2, p. 173] - notwithstanding that nothing in either country's textile oeuvre correlates with these rugs. It has long been conceded that Armenians could have woven these carpets but for various unconvincing reasons could not have been the original source of the design. Most of these arguments depend upon little more than spurious logic, tendentious ethnic claims or comparisons with Russian-era designs, none of which, either individually or collectively, constitute a valid intellectual standard. In more recent years the debate, regrettably, has been inflamed by regional ethnic and political animosities that can only further cloud the debate and challenge the impartiality of those engaged in it.

\section{References}

1 Kerimov, L., Azerbaijan Carpets, Baky Jazychy, Baku (1985).

2 Bier C., 'Carpets for commerce: rug weaving in the Caucasus', in Textiles in Trade: Proceedings of the Textile Society of America Biennial Symposium, Textile Society of America, Washington (1990) 166-173.

3 Pope A. U., 'The myth of the Armenian dragon carpets', Jahrbuch der Asiasiatischen Kunst 11 (1925) 147-158.

4 Neressian,V., 'The Marcy-Indjoudian Cope', Ars Orientalis 40 (2011) 204-241.

5 McGinnis, J., 'A Neo-Assyrian text describing a royal funeral', State Archives of Assyria Bulletin 1(1) (1987) 1-13.

6 Hubel, R., The Book of Carpets, Washington International Associates, Washington (1971).

7 Schurman U., The Pazyryk, Its Use and Origin, Armenian Rug Society, New York (1982).

8 Franses, M.; R. Pinner, R., 'The Caucasian collection', Hali 3 (1980) 96-115.

9 Spooner, B., 'Weavers and dealers: the authenticity of the oriental carpet', in The Social Life of Things: Commodities in Cultural Perspective, ed. A. Appadurai, Cambridge University Press, Cambridge (1986) 195-235, https://doi.org/10.1017/ CBO9780511819582.009.

10 Malcolm, J.; Browne E. G., 'Account of a rare manuscript: History of Issfahán, presented to the Royal Asiatic Society on May 19, 1827', The Journal of the Royal Asiatic Society of Great Britain and Ireland 33(4) (1901) 411-446.

11 Gans-Ruedin, E., Iranian Carpets: Art, Craft and History, Thames and Hudson, London (1978).

12 Bode, W von; Kühnel, E. Antique Rugs from the Near East, Bell and Hyman, London (1984).

13 Kendrick, A., Guide to the Collection of Carpets, Victoria and Albert Museum, London (1915).
14 Kendrick, A.; Tattersall, C., Fine Carpets in the Victoria and Albert Museum, Charles Scribner's Sons, New York (1924).

15 Valentiner, W., Catalogue of a Loan Exhibition of Early Oriental Rugs, Metropolitan Museum of Art, New York (1910).

16 Breck, J.; Morris, F., The James F. Ballard Collection of Oriental Rugs, Metropolitan Museum of Art, New York (1923).

17 Kendrick, A. F., 'An exhibition of Near Eastern carpets', The Burlington Magazine for Connoisseurs 55 (1929), 15-16.

18 Sakisian, A. 'Les tapis a dragons et leur origine arménienne', Syria 9(3) (1928), 236-258.

19 Willborg, P., 'The dragon rugs of Anatolia - a discussion of the type, its origin and age', Medelhavsmuseet: Bulletin, 18 (1983) 78-85.

20 Franses, M., 'Safavid-style domestic embroideries from historical Azerbaijan, 1550-1800', in Stars of the Caucasus: Silk Embroideries from Azerbaijan, ed. M. Franses, M. Carey \& S. Krody, Hali Publications Limited, London (2018) 49-105.

21 Eiland, M. L., Jr.: Eiland, M. L., III, Oriental Carpets: A Complete Guide, Bullfinch Press, Boston (2001).

22 Der Manuelian, L.; Eiland, M., Weavers, Merchants and Kings: The Inscribed Rugs of Armenia, Kimbell Art Museum, Fort Worth (1984).

23 Wright, R.; Wertime, R., Caucasian Carpets and Covers, Hali Publications Ltd., London (1995).

24 Mankowski, T., 'Some documents from Polish sources relating to carpet making in the time of Shah Abbas I' in $A$ Survey of Persian Art from Prehistoric Times to the Present, eds. A. U. Pope \& P. Ackerman, vol. 3, Oxford University Press, New York (1938) 2431-2436.

25 Azadi, S.; Kerimov, L.; Zollinger, W., Azerbaijani-Caucasian Rugs: The Ulmke Collection, Paul Hartung, Hamburg (2001).

26 Gerber, J., Description of Countries and Peoples along the Western Shore of the Caspian Sea, Oriental Literature, Moscow (1963).

27 Preiser-Kappler, J., 'The significance of Tabriz in the spatial frameworks of Italian merchants and ecclesiastics in the 13th and 14th centuries', in Politics, Patronage and the Transmission of Knowledge in 13th-15th Century Tabriz, ed. J. Pfeiffer, Brill, Leiden (2014) 251-300.

28 Barbaro, G., Travels to Tana and Persia, Hakluyt Society, London (1873).

29 Sergeant, R., 'Material for a history of Islamic textiles up to the Mongol conquest', Ars Islamica 10 (1943) 71-104.

30 Het'um, The Flower of Histories of the East, Sources of the Armenian Tradition, Long Branch (2004).

31 Tavernier, J-B, The Six Voyages of Jean Batiste Tavernier through Turkey and into Persia and the East Indies, London (1678).

32 J. Bell, Travels from St. Petersburg in Russia to Diverse parts of Asia, vol. 1, Glasgow (1763).

33 Cartwright, J., 'Observations of Master John Cartwright in his voyage from Aleppo to Hispahan, and backe again', in Hakluytus Posthumous or Purchas His Pilgrimes, ed. S. Purchas, vol. 8, University of Glasgow Press, Glasgow (1906).

34 Herzig, E., 'The Armenian merchants of New Julfa, Isfahan', $\mathrm{PhD}$ dissertation, St. Anthony's College, Oxford University (1991).

35 Erdmann, K., Seven Hundred Years of Oriental Carpets, University of California Press, Berkeley (1970).

36 Dimand, M.; Mailey, J., Oriental Rugs in the Metropolitan Museum of Art Metropolitan Museum of Art, New York (1973). 
37 Pope, A. U., A History of Persian Art Since the Seventh Century A.D., Peter Davies, London (1930).

38 Ellis, C. G., Early Caucasian Rugs, Textile Museum, Washington (1975).

39 Kurdian, H., 'Corrections to 'Myth of Armenian Dragon Carpets", Journal of the Royal Asiatic Society of Great Britain and Ireland 1 (1940) 65-67, https://doi.org/10.1017/ S0035869X00079375.

40 Kouymjian, D., 'The Berlin Dragon-Phoenix Carpet and its probable Armenian origin', in Armenian Rugs and Textiles. An Overview of Examples from Four Centuries. Exhibition Catalogue, Armenian Rugs Society, Vienna (2014) 16-31.

41 Pope, A. U., 'Les tapis à Dragons. Résponse de M. U. Pope à l'étude de M. Sakisian', Syria 10(2) (1929) 181-182.

42 Sims, E., 'Carpets viii: The Il-Khanid and Timurid Periods' (1990), Encyclopaedia Iranica, http://www.iranicaonline. org/articles/carpets-viii (accessed 2018-12-02).

43 Monteith, W., Notes on Georgia and the New Russian Conquest beyond the Caucasus, Foreign and Commonwealth Office Collection, London (1829).

44 Lynch, H. Armenia: Travels and Studies, vol. 1, Longmans, Green and Company, London (1901).

45 G. Bournoutian, The 1820 Russian Survey of the Khanate of Shirvan, Gibb Memorial Trust, Cambridge (2016).

46 Bell, H., 'Carpets: Introduction', in Special Loan Exhibition of Carpets and Other Textiles form Asia Minor, Pennsylvania Museum and School of Industrial Art, Philadelphia (1919).

47 Tanavoli, P., Persian Flatweaves, Antique Collectors Club, London (2002).

48 Azadi, S. 'Carpets xiv: Tribal Carpets' (1990), in Encyclopaedia Iranica, http://www.iranicaonline.org/articles/carpets-xiv (accessed 2018-12-02).

49 Denny, W., The Classical Tradition in Anatolian Carpets, The Textile Museum, Washington (2002).

50 W. Brice, 'The Turkish colonization of Anatolia', Bulletin of John Ryland's Library 38 (1955) 18-44, https://doi. org/10.7227/BJRL.38.1.2.

51 Spooner, B., 'The Iranian deserts', in Population Growth: Anthropological Implications, ed. B. Spooner, The MIT Press, Cambridge (1972) 245-268.

52 Jacoby, D., 'Silk economics and cross-cultural artistic interaction: Byzantium, the Muslim World, and the Christian
West', Dumbarton Oaks Papers 58 (2004) 197-240), https:// doi.org/10.2307/3591386.

53 Sharkey, H., A History of Muslims, Christians and Jews in the Middle East, Cambridge University Press, Cambridge (2017), https://doi.org/10.1017/9781139028455.

54 Arkun, A., 'Into the modern age, 1800-1913' in The Armenians: Past and Present in the Making of National Identity, ed. E. Herzig \& M. Kurkchiyan, Routledge Curzon, New York (2005) 40-65.

55 The Book of Ser Marco Polo, the Venetian, London (1903).

56 Grasset-Saint Sauver, J. 'Habitan de l'Armenie', in Encyclopédie des Voyages, Paris (1796).

57 Hammer, E.; Arbuckle, B., '10,000 years of pastoralism in Anatolia: a review of evidence for variability in pastoral lifeways', Nomadic Peoples 20(2) (2017) 214-267, https://doi. org/10.3197/np.2017.210204.

58 Wallerstein, I., The Modern World System: Capitalist Agriculture and the Origins of the European World Economy in the Sixteenth Century, vol. 1, Academic Press, New York (1974).

59 Brüggeman, W., 'The Islamic oriental carpets in Giotto's fresco Christmas Mass at Greccio in Assisi', in Facts and Artefacts in the Islamic World: Festschrift for Jens Kröger on His 65th Birthday, eds. A. Hagedorn \& A. Shalem, Brill, Leiden (2007) 373-393.

60 Siegelbaum, L. H., 'Exhibiting kustar industry in late imperial Russia / exhibiting late imperial Russia in kustar industry', in Transforming Peasants: Society, State and Peasantry, 18611930, ed. J. Pallot, Macmillan and Company, London (1998) 37-63, https://doi.org/10.1007/978-1-349-26526-8_3.

Received: $2018-3-22$

Revised: 2018-10-15

Accepted: 2018-10-19

Online: $2018-12-3$

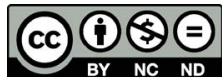

This work is licensed under the Creative Commons

Attribution-NonCommercial-NoDerivatives 4.0 International License.

To view a copy of this license, visit http://creativecommons.org/licenses/by-nc-nd/4.0/deed.en. 